\title{
R\&D, STRUCTURAL CHANGE AND PRODUCTIVITY: THE ROLE OF HIGH AND MEDIUM-HIGH TECHNOLOGY INDUSTRIES
}

\author{
Celeste Amorim Varum ${ }^{*}$ \\ Bruno Cibrão ${ }^{\dagger}$ \\ António Morgado ${ }^{\ddagger}$ \\ JOANA COSTA
}

\begin{abstract}
Resumo
Este artigo investiga o potencial impacto do aumento de I\&D e de mudanças estruturais na produtividade do trabalho em Portugal. Com base na literatura sobre a relação entre despesas em I\&D, mudança estrutural e produtividade, avaliamos a contribuição da I\&D e das indústrias de alta tecnologia neste cenário durante os últimos 30 anos. Os resultados obtidos confirmam a importância dos investimentos em I\&D das empresas de indústrias de alta e média-alta tecnologia e I\&D público no crescimento da produtividade. Não obstante, não podemos afirmar que este fenômeno tenha como esteio principal o crescente relevo destas indústrias.
\end{abstract}

Palavras-chave: I\&D, Mudança Estrutural, Produtividade.

\begin{abstract}
This paper investigates the potential impact of increased R\&D efforts and structural change in Portugal on labour productivity. Based on existing literature on the relation between R\&D expenditures, structural change and productivity, we evaluate the contribution of R\&D and hightech industries to productivity over the last 30 years. Our results confirm the importance of business R\&D in the medium to high-tech sectors and of public $R \& D$, as they stimulate productivity growth. However, we cannot support the hypothosis that productivity growth was primarily rooted in the development of medium-high technology industries.
\end{abstract}

Keywords: R\&D, Structural Change, Productivity

JEL classification: $\mathrm{O} 30, \mathrm{O} 40$

\footnotetext{
* Department of Economics, Management and Industrial Engineering, University of Aveiro. Address: Universidade de Aveiro, DEGEI, 3810-193 Aveiro, Portugal. Email: camorim@ua.pt

† bcibrao@gmail.com

‡ajrsm@ua.pt

$\S$ joanacosta@ua.pt
} 


\section{Introduction}

The economic competitiveness of economies may be broadly analysed on the basis of a set of indicators, that is, production performance, productivity, innovation and international trade performance. Recent data on these indicators has given rise to serious concerns over the comparative performance of Portugal (and even Europe ${ }^{1}$ ) over the last 15 years or so.

The data for Portugal reveal that after the high-growth "new-economy" years of the second half of the last decade, growth has been considerably below the average of the European Union (EU hereafter) ${ }^{2}$. By 2005, Portuguese GDP per capita and real GDP per hour worked amounted to just 75 and 68 percent of the EU average respectively. Increasing productivity emerged as the main economic challenge for Europe and for Portugal in particular.

Conscious of the gap, and in line with the European directives, in 2005 Portugal launched the Technological Plan with the goal of fostering growth and competitiveness. The overall goal has been embedded in a set of policy guidelines that include the following axes:

1. Knowledge - To qualify the Portuguese as a knowledge society, fostering structural measures which aim at enhancing the average qualification level of the population, implementing a broad and diversified lifelong learning system and mobilizing the Portuguese to be an Information Society;

2. Technology - To overcome the scientific and technological gap, reinforcing public and private scientific and technological competencies and recognizing the role played by enterprises in the process of the creation of qualified jobs and Research \& Development (R\&D) related activities;

3. Innovation - To boost Innovation, helping the production chain to adapt to the challenges of Globalization by means of the diffusion and development of new procedures, organizational systems, services and goods.

Within the specific objectives and targets, the attention diverted towards the need to increase the value added per employee, and thus to reducing the gap with the EU, is notable. The increase of public and business $R \& D$ is also a priority and a specific objective of the plan. Medium and high-tech industries deserve particular emphasis in the Technological Plan. The data from the year base and of the Portuguese targets related to $R \& D$ and industrial structural change are reflected in Table 1.

These aims and targets of the plan are clearly understood within a context of generalized acceptance of the nexus between innovation, structural change

\footnotetext{
${ }^{1}$ Motivating the Lisbon Strategy in 2000 and its 2005 refocus on the objectives of jobs and growth.

${ }^{2}$ In our article we considered the data up to 2005 . Hence, we considered the 25 countries that were members of the European Union in that year (EU-25). We bear in mind that up to 2003 the European Union was formed by 15 countries (EU-15). The old Member States are Austria, Belgium, Denmark, Finland, France, Germany, Greece, Ireland, Italy, Luxembourg, the Netherlands, Portugal, Spain, Sweden and the United Kingdom. On 1 May 2004 ten new countries joined the EU. This ambitious step in the history of Europe was marked by the integration of Cyprus, the Czech Republic, Estonia, Hungry, Latvia, Lithuania, Malta, Poland, Slovakia and Slovenia. The 25-member EU now forms a political and economic area. Bulgaria and Romania signed their accession treaty on 25 April 2005. They became members of the EU on 1 January 2007. Now the $\mathrm{EU}$ is formed of 27 member states.
} 
Table 1: Selected targets of the Portuguese Technological Plan

\begin{tabular}{|c|c|c|c|c|}
\hline \multicolumn{2}{|c|}{ Indicators and measures } & \multirow{2}{*}{$\begin{array}{l}\text { Target for } \\
2010(\%)\end{array}$} & \multicolumn{2}{|c|}{$\begin{array}{l}\text { Value (\%) in } \\
2002 / 3^{*}\end{array}$} \\
\hline & & & Portugal & EU-25 \\
\hline \multirow{2}{*}{ S\&T } & $\begin{array}{l}\text { Public spending in } \mathrm{R} \& \mathrm{D} \text { as } \\
\text { percentage of GDP }\end{array}$ & 1 & 0.6 & 0.7 \\
\hline & $\begin{array}{l}\text { Business spending in R\&D as } \\
\text { percentage of GDP }\end{array}$ & 0.8 & 0.3 & 1.3 \\
\hline \multirow{4}{*}{$\begin{array}{l}\text { Competitiveness } \\
\text { \& Innovation }\end{array}$} & $\begin{array}{l}\text { Employment in medium and } \\
\text { high-tech industries as per- } \\
\text { centage of total employment }\end{array}$ & 4.7 & 3.1 & 6.6 \\
\hline & $\begin{array}{l}\text { Value added of medium and } \\
\text { high-tech industries }\end{array}$ & 6.2 & 4.9 & 15.8 \\
\hline & $\begin{array}{l}\text { Exports of high-tech as per- } \\
\text { centage of total exports }\end{array}$ & 11.4 & 7.4 & 17.8 \\
\hline & $\begin{array}{l}\text { Creation of firms in medium } \\
\text { and high-tech sectors as per- } \\
\text { centage of total } n^{\circ} \text { of enter- } \\
\text { prises creation }\end{array}$ & 12.5 & n.a. & n.a. \\
\hline
\end{tabular}

and productivity. It is often argued that $R \& D$ and high-tech industries drive growth processes, and that they are the sources of growth in output, employment and productivity in the knowledge economy. Following Kaloudis \& Smith (2005), a broad set of hypotheses are implied in these R\&D-biased explanations of growth. We highlight the following:

1. Innovation accounts for a significant part of modern economies' growth;

2. There should be a significant correlation between shares of high-tech in total output and levels/growth rates of productivity and GDP.

Regarding the first hypotheses, the relation between R\&D and productivity is strongly accepted in the literature. Even still, Griliches (1995) argues that the scientific and quantitative support for the relationship between the two aspects is rather limited. As for the impact of changes in industrial structure, it is widely recognized that the most technologically developed industries are more productive than the remainder (Aiginger 2001). However, empirical evidence on the contribution of structural change within manufacturing to productivity is rather scarce and far from consensual (Kaloudis \& Smith 2005).

In what follows we explore the theoretical support for these hypotheses and test them in the Portuguese case. Because high-tech industries, by definition, are all located within manufacturing, we focus in this paper primarily on the manufacturing sector. This study presents estimates of the contribution of R\&D and structural change to productivity growth in the Portuguese Manufacturing Industry (PMI) over the period 1980-2003. It contributes to the existing literature in this field of analysis in two ways. First, the major sources of new technology are taken into account simultaneously: public 
R\&D and business R\&D in medium to high-tech sectors. Second, an attempt is made to evaluate the impact of the increasing weight of medium to hightech industries in manufacturing employment. The results are intended to provide insights into the following:

1. The contribution of public research to productivity growth;

2. The contribution of business $R \& D$ in high-tech sectors to productivity growth;

3. The importance of structural transformation on innovation intensive sectors to productivity growth.

The article is organized as follows. In the next section we provide the theoretical background to analyse the relationship between $R \& D$ and productivity and then between structural change and productivity. In section 3 we point to the critical aspects of Portuguese competitiveness and present a brief characterization of the manufacturing industry over the period 1980-2003. We also present our empirical study. Finally section 4 derives policy implications and further research avenues.

\section{Productivity, R\&D and industrial structure}

In this section we discuss the relationships between productivity, $R \& D$ and industrial structure. These are used to define the hypotheses to be tested in the context of the Portuguese economy.

\subsection{R\&D and productivity}

"It is now well-known that both the governments of and private firms in most industrialised countries have devoted an increasing amount of resources to $R \& D$. One of the main objectives of economic analysis is to evaluate whether the returns on this investment justify the initial expenditure. To this end, the relationship between R\&D and productivity growth has been investigated at different levels of aggregation: economy, sector, industry and firm." (Aiginger 2001)

The relationship between $\mathrm{R} \& \mathrm{D}$ and the productivity of a country is commonly accepted in the literature. R\&D resulting in new goods, new processes and new knowledge, is generally accepted as a major source of technical change. As defined by the Frascati Manual (OECD 1994), R\&D “comprises creative work undertaken on a systematic basis in order to increase the stock of knowledge and the use of this stock of knowledge to devise new applications".

The relationship between $R \& D$ and innovation is a complex and a nonlinear one. In order to capture the links between R\&D and productivity it is necessary to take several aspects into account. First, there are different types of $R \& D$, and the effects of $R \& D$ on productivity may work through various channels. Second, R\&D is not the only source of new technolog. In modern and industrial economies, other activities such as learning by doing or design are conducted in most cases on the basis of new technology coming out of 
R\&D (e.g. changes in the organization of business related to the use of information and communication technology).

However, it is also recognized that it is difficult to incur substantial advances in technology without work undertaken on a systematic basis and R\&D is a good indicator of this broader phenomenon.

There is major evidence that links R\&D to productivity. In modern growth economies, it is clear that the inputs of capital and labour alone cannot account for a large part of output growth (Solow 1957). In the rich empirical tradition of work on productivity growth, the total productivity growth factor has been related to the accumulation of "knowledge stock", which is not accounted for in the measurement of the conventional stock of capital, but increases output via innovation and technological change. Economic theory (Solow 1957, Romer 1990) points to technical change as the major source of productivity growth in the long run. R\&D expenditures have been suggested as a way of measuring this knowledge stock, giving rise to a range of works relating $R \& D$ expenditures and productivity.

In Griliches (1979) discussed issues in assessing the contribution of R\&D to productivity growth, and in 1980 he evaluated the returns of R\&D expenditures in the private sector, using cross-sectional data from a set of companies over the period 1957-1963. The results reveal a positive correlation between $R \& D$ expenditure and the productivity achieved by the companies, which is given by a positive coefficient of the $R \& D$ of about 0.07 . In a later work, Griliches (1995) discussed the econometric results and measurement issues in the relationship between $R \& D$ and productivity. In his review, he refers to the co-existence of three alternatives to analyse the relationship: case studies, econometric studies and the statistical analysis of patents. He concludes that the economic literature placed particular emphasis on econometric studies, mainly the Cobb-Douglas production functions and the $\mathrm{CDM}^{3}$ model.

Guellec \& Van-Pottelsberge (2001) studied different types of R\&D and analyzed their long-term effects on multifactor productivity growth. Using a sample of 16 OECD countries over the period 1980-98, they found that an increase of $1 \%$ in business $\mathrm{R} \& \mathrm{D}$ leads to a rise of productivity in $0.13 \%$. The effect is larger in countries where the share of defense-related government funding is smaller. If, on the other hand, foreign $R \& D$ increases by $1 \%$, then productivity will rise by $0.46 \%$. Finally, an increase of $1 \%$ in public R\&D generates an increase of $0.17 \%$ in productivity growth. The effect is larger in countries where the share of universities (as opposed to government labs) is higher and in countries where the share of defence $R \& D$ is smaller. They also concluded that the effects of $R \& D$ are higher in countries with higher business R\&D intensity.

Mairesse (2004) presents a model which quantifies the links between R\&D, innovation and productivity on a panel of 4164 firms. According to his results, firms with a $20 \%$ share of innovative sales would be $15 \%$ more productive than firms with just $5 \%$ in innovative sales. In the same vein, the productivity of a firm that has filed two European patents would be nearly $10 \%$ higher than that of a firm having filed a single patent.

Like Mairesse, Wieser (2001) investigated the contribution of R\&D to productivity performance at the micro level. Wieser's study presents a review of the literature which demonstrates a significant impact of R\&D on firm per-

\footnotetext{
${ }^{3}$ Crépon et al. (1998).
} 
formance, but reveals that the extent of the impact differs widely. Based on his own empirical work for a sample of 2167 large, publicly traded firms in Europe and the US, he also confirms the positive and significant contribution of $R \& D$ to productivity growth, once that his results point to a private rate of return on $R \& D$ of about $12 \%$.

These papers also discuss the fact that the impact of R\&D on the economy goes well beyond the direct private returns to the innovator or to the industry where it occurs. Indeed, early work on $R \& D$ concentrated only on the returns to firms and industries. However, more recently, spurred by comments in Griliches $(1979,1992)$, attention shifted towards spillovers effects. Since then a number of empirical studies demonstrate the existence of positive spillovers, identifying a private return as well as a social return from privately funded R\&D investment. Fraumeni \& Okubo (2005) as well as Sveikauskas (2007) review the literature on $\mathrm{R} \& \mathrm{D}$ and productivity growth, showing that the overall rate of return to $R \& D$ is very large - about $25 \%$ for private return and $65 \%$ for social return. These two articles selected nine studies to determine the rate of return on privately funded $R \& D$.

Most studies suggest that the private return from $R \& D$ represents only a third of the social return from $\mathrm{R} \& \mathrm{D}^{4}$. Therefore, Wieser (2001) asserts that the incentives for the private sector to invest in $R \& D$ do not properly reflect the value that society receives from that research ${ }^{5}$. This is one argument for the participation of government in national $R \& D$ activities. Hence, the greater the divergence between the private and social returns of $R \& D$, the stronger is the argument for the involvement of government in these activities (Wieser 2001).

Government and university research has direct effect on scientific knowledge and public missions, once it generates basic knowledge (Adams 1990, Brooks 1994). In many cases, the effect of government research on productivity is not measured, either because it is indirect or because its results are not integrated into existing measures of GDP (Health-related research allows improving the length and quality of life, which are not taken into account in GDP measures). Basic research, performed mainly by universities, enhances the stock of knowledge of the society. New knowledge is not considered as an output in the current system of national accounts (contrary to physical investment and software, for instance), and as such it is not included in GDP measures, hence the direct outcome of basic research is overlooked. However, basic research may open new opportunities for business research, which in turn affects productivity (Adams 1990, Brooks 1994, Guellec \& Van-Pottelsberge 2001).

It is therefore not surprising that there have been very few studies on the effects of public research on productivity. Only some components of public research have been used in empirical frameworks. For instance, Adams (1990) finds that fundamental stocks of knowledge, proxied by accumulated academic scientific papers, significantly contributed to productivity growth in US manufacturing industries. Another example is provided by Poole \& Bernard (1992) for military innovations in Canada, who present evidence that

\footnotetext{
${ }^{4}$ In most of these studies, "private" returns reflect industry returns, not the traditional returns to firms. Sveikauskas (2007) discusses how the different studies addressed this issue.

${ }^{5}$ Considering market failure, there is vast discussion on how to promote R\&D. There are basically two alternatives. One is direct intervention from the state through public R\&D (addressed in this paper). The other is the strengthening of property rights.
} 
a defense-related stock of innovation has a negative and significant effect on the total productivity growth factor of four industries over the period 196185.

As seen previously, the idea that innovation stimulated by R\&D expenditure makes an important contribution to productivity growth has been demonstrated by several authors. However, the relationship between innovative activities, innovation itself and productivity is rather complex and far from consensual. In fact, other authors suggest the existence of a negative correlation between innovation and productivity in the short run Young (1991), Utterback (1994), Jovanovic \& Nuarko (1996), Christensen (1997), Ahn (1999), Bessen (2002).

Due to the rapid progress in the number and quality of studies focused on the relation between $R \& D$ and productivity, our knowledge concerning these issues has seriously improved in the last two decades. Nevertheless, it remains rather modest because of the substantial difficulties in measurement and in the statistical inference of causal relationships from non-experimental data (Mairesse 2004).

\subsection{Structural change and productivity}

The relationship between the economic structure of a country and its productivity growth has received more attention in recent decades. Salter (1960) was the first to emphasize the importance that a structural change (modifications in the sectoral localization of labour, or possibly in the production factors in general) can have in boosting productivity.

Since then, several authors have studied the relocation of inputs in the manufacturing industry, because although there is no doubt as to the productivity gains resultant from the shift of inputs from agriculture to manufacturing (Syrquin 1988), the consequences of movements that occur inside the manufacturing industry are not very clear (Rocha 2005).

While Salter (1960) presents significantly strong results about the benefits of structural changes in the UK economy between 1924 and 1950, more recent studies (Fagerberg 2000, Timmer \& Szirmai 2000, Carree 2002, Kiliçaslan \& Taymaz 2004, Singh 2004) as we shall see below show more limited results. Some studies present a negligible or even a negative contribution of structural change to productivity growth (Singh 2004, Kiliçaslan \& Taymaz 2004, Kaloudis \& Smith 2005).

Fagerberg (2000) focused on the impact of specialization and structural changes on productivity growth in manufacturing, using a sample of 39 countries and 24 industries over the period 1973-1990. The results reported in his study indicate that structural change still matters, but in a different way than before, because unlike what happened in the first half of the last century, the most technologically sophisticated industries decreased their shares in total employment between 1970 and 1990. In fact, the data suggest that in the sample studied by Salter, $1 \%$ higher productivity growth was associated with $1.4 \%$ higher growth in employment, while in Fagerberg's sample the relationship between productivity growth and employment is less than one half of that level. Even considering that, he argues that countries that have managed to increase their presence in the technologically most progressive industries like electronics (the so called "electronics revolution"), have 
experienced higher productivity growth in their manufacturing sectors than other countries, due to important spill-over effects.

Similar evidence to that of Fagerberg (2000) is presented by Timmer \& Szirmai (2000), but in this case on four Asian countries ${ }^{6}$ and 13 subsectors of the manufacturing industry over the period 1963-1993.

Adding to Fagerberg (2000), Carree (2002) seeks to complement the analysis by estimating the impact of the employment share of technologically progressive industries using a different methodology. Fagerberg claims that an increase in the "electronics" industry in total employment will generate higher productivity growth in the manufacturing sector. However, the size of the impact, and as a consequence the extent of spillover, is found to be much smaller than estimated by Fagerberg.

The relationship between structural changes and productivity growth in the manufacturing sector is also investigated by Singh (2004) in his study on South Korea over the period 1970-2000. The results show that in the 1970s a structural bonus occurred (productivity gains due to the structural change). However, between 1980 and 2000 the relocation of inputs in the manufacturing sector has not ensured benefits in productivity.

Kiliçaslan \& Taymaz (2004) found similar results in their study on the relationship between industrial structure, productivity and competitiveness in manufacturing industries for a sample of $\mathrm{MENA}^{7}$ and Asian ${ }^{8}$ countries from 1965 to 1999. This study shows that the impact of the structural change in the productivity growth of the manufacturing sector is negligible for most countries, especially since the 1980s. In this period, countries like Jordan and Korea present a negative correlation between structural change and the productivity growth.

Using simple correlation analysis, Kaloudis \& Smith (2005) study of 11 OECD economies for a 23-year period (1980-2002) with data from the OECD's STAN database, concluded that structural change (share of the electronics and other high-tech industries) within manufacturing was not the direct cause of the growth in advanced OECD economies. They did not find evidence supporting the argument that the high-tech economies are also the high growth economies. They assert that different economies can follow different paths of economic growth. Countries play different roles in the differentiated international economic system with clear patterns of division of labour among the highly developed economies.

Kaloudis \& Smith (2005) show that the higher the share of high-tech industries in manufacturing value added, the higher is GDP per inhabitant. Looking at income levels first, there is indeed a relationship between technological intensity and the level of income across national economies. However, they did not find any positive relationship when we compare the hightech share in manufacturing value added with the rate of growth of GDP per inhabitant. They cannot conclude, therefore, that high-tech economies are also high growth economies. Moreover, an additional important point is the absence of any convincing evidence for the hypothesis that low-tech economies are low growth economies. If anything, there is weak evidence in

\footnotetext{
${ }^{6}$ India, Indonesia, South Korea and Taiwan.

${ }^{7}$ Middle East and North Africa (MENA): Egypt, Iran, Jordan, Kuwait, Malta, CityMarocco, Tunisia and Turkey.

${ }^{8}$ Malaysia, Indonesia, Korea, India and Pakistan.
} 
Table 2: Real GPD growth, and real GPD per capita (EU25=100)

\begin{tabular}{|c|c|c|c|c|}
\hline & \multicolumn{3}{|c|}{ Annual GDP Growth (\%) } & \multirow{2}{*}{$\begin{array}{l}\text { GDPpc } 2005 \\
(\text { EU25=100) }\end{array}$} \\
\hline & 1990-1995 & $1995-2000$ & 2000-2005 & \\
\hline Portugal & 1.7 & 4.1 & 0.6 & 75 \\
\hline EU-25 & 1.7 & 3.0 & 1.8 & 100 \\
\hline USA & 2.5 & 4.1 & 2.4 & 152 \\
\hline
\end{tabular}

${ }^{a}$ Source: European Commission (2006a), Table 2.1.

the data that low-tech economies are higher growth economies than the hightech economies. This evidence suggests that growth does not rest on high-tech driven structural change.

Another fundamental question raised by Kaloudis \& Smith (2005) is in which way the causality runs, since high-tech industries have in practice been created via significant government support, and have invariably been initiated by substantial publicly-supported R\&D infrastructures (Mowery \& Rosenberg (1989), as well as Bruland \& Mowery (2004) provide good overviews of this discussion). There may therefore be a pattern of causality that runs from high levels of income, to government budgetary positions, to the creation of industries - that is, some R\&D-intensive industries may be a consequence of high income, not a cause of it.

\section{Productivity, R\&D and structural change: an analysis of the Portuguese manufacturing industry}

\subsection{Overview of the Portuguese competitiveness}

We selected Portugal to test our hypotheses because it is a good example of a country urgently catching-up with developed economies and currently has a clear policy and concern for R\&D and structural change. The Portuguese experience can also be valuable for other economies facing similar challenges.

We shall now briefly summarize some of the significant aspects with respect to Portuguese competitiveness. We consider what recent data tells us about the EU in general and the Portuguese economy in particular. The data for Portugal reveal that after the high-growth "new-economy" years of the second half of the last decade, growth has been considerably below the average of the EU-25. By 2005, Portuguese GDP per capita amounted to just 75 percent of the EU-25 average, as we can see in Table 2.

Table 3 presents labour productivity growth rates in Portugal, the EU-25 and the US. The data clearly points towards a loss of competitiveness of the EU-25 as compared with the US from the mid-1990s onwards ${ }^{9}$. Portugal registered low labour productivity growth overall. By 2005, real GDP per person employed corresponded to 66 percent of EU-25 labour productivity. Increas-

\footnotetext{
${ }^{9}$ In the period of 2000-2005, and by historical standards, TFP growth in the EU was very low. The explanations put forward to explain EU TPF performance vary between those that highlight limited innovation, undeveloped services, issues of regulation and infrastructures (European Commission, 2006a). Also, the picture is quite differentiated across EU member states. For instance, Nordic and Anglo-Saxon countries in general have TFP growth rates that are high by global standards and in some cases higher than those of the US while, at the opposite end, most Southern European countries performed poorly.
} 
Table 3: Labour productivity per person employed (ppe)

\begin{tabular}{lcccc}
\hline & \multicolumn{2}{c}{ Annual Labour productivity growth (\%) } & Real GDPppe 2005 \\
\cline { 2 - 4 } & $1990-1995$ & $1995-2000$ & $2000-2005$ & \\
(EU25=100)
\end{tabular}

Source: European Commission (2006a), Table 2.3.

Note: Productivity is calculated considering persons employed (ppe)

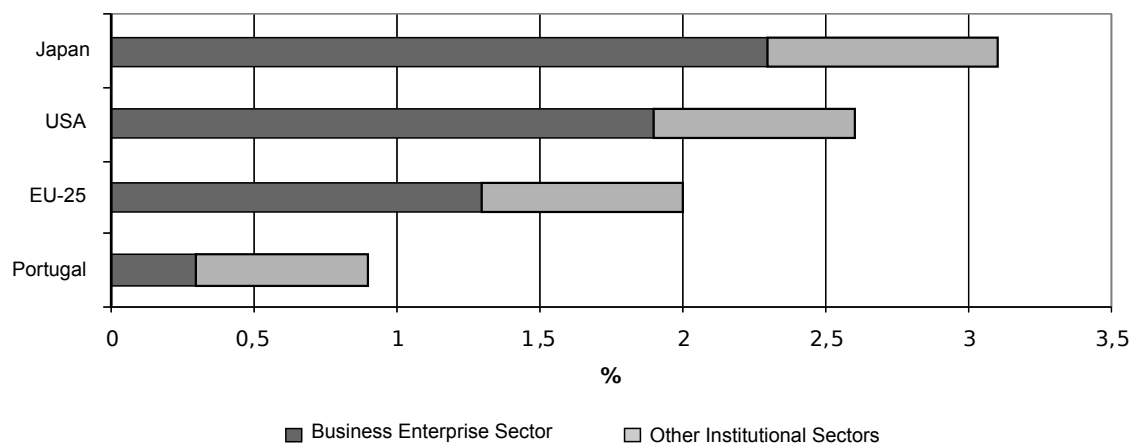

Source: Science and Technology - Statistics in Focus (2005), Eurostat.

Figure 1: R\&D intensity in the EU-25, USA, Portugal and Japan - 2002

ing productivity emerged as the main economic challenge for Europe and Portugal in particular.

With regard to innovation indicators, the picture is not very encouraging in spite of considerable advances. Data on R\&D intensity (R\&D expenditures as a percentage of GDP) reveals that Portugal is well below the EU-25 average. Business expenditures in $R \& D$ in particular are relatively smaller than in other European counterparts, while public expenditures represent the largest share of total R\&D in the country.

Economies are ranked by The European Innovation Scoreboard (European Commission, 2006c) according to a summary innovation index (SII) that combines five different dimensions, grouped in inputs and outputs ${ }^{1011}$. As far as Portugal is concerned, it is part of a group (Slovenia, Czech Republic, Lithuania, Poland, Latvia, Greece and Bulgaria) of countries catching-up with the leaders SII scores well below the EU-25, albeit with a faster than average improvement in innovation performance. Public R\&D contributed significantly to that end, albeit the data of private R\&D intensity in manufacturing overall

\footnotetext{
${ }^{10}$ At the innovation inputs level: Innovation drivers (four indicators, measuring the structural conditions of innovation potential), knowledge creation (4 indicators, measuring investments in R\&D activities, considered key elements in a successful knowledge-based economy), innovation and entrepreneurship ( 6 indicators, measuring the efforts towards innovation at the firm level). Innovation outputs include two dimensions, namely applications ( 5 indicators, measuring the performance, expressed in terms of labour and business activities, and their value added in innovative sectors) and intellectual property ( 5 indicators, measuring the results achieved in terms of successful know-how).

${ }^{11}$ A comparison with the US and Japan indicates that both are still ahead of the EU-25 in terms of innovation performance.
} 
also shows considerable improvements since 1980.

Developments in manufacturing have an important role in the overall performance of the economy. Recall that in Europe (EU-25), manufacturing accounts for about a third of employment and value-added (EUROSTAT 2004). In Portugal the share for manufacturing is similar. By 2003, the Portuguese manufacturing (section D $)^{12}$ accounted for 28 percent of the value added and employment ${ }^{1314}$. Hence, our empirical analysis focuses on the nexus of $R \& D$, structural change and productivity within the Portuguese manufacturing industry.

\subsection{Empirical analysis}

\section{Data}

The data considered in this part of the study are mainly based on three basic concepts: R\&D expenditures, employment and value added. The National Statistics Institute of Portugal (Instituto Nacional de Estatística) and the R\&D Survey from the Science and Higher Education Observatory (Observatório da Ciência e do Ensino Superior) are our primary data sources to estimate the econometric model over the period 1980-2003. In this study, we had to overcome the obstacle of a change in methodology by the National Statistics Institute of Portugal in 1990 with regard to data collection of employment and value added. Recall that until 1989 the data published by the National Statistics Institute of Portugal was obtained through a survey of a sample of firms. Since 1990, the data from INE considers all firms. In order to have a consistent series, we calculated the values would corespond to all firms for the years 1980-1989. We started by calculating what would be the 1989 value under the new methodology $\left(Y^{*}\right)$, which assumed that the annual growth rate for 1989-1990 was the same of the annual compound growth rate ${ }^{15}$ over the period 1990-2003, $\alpha_{1990-2003}$ :

$$
\alpha_{1990-2003}=\left[\exp \left(\frac{1}{t} \times\left(\ln Y_{2003}-\ln Y_{1990}\right)\right)-1\right] \times 100
$$

being $t$ the number of years

We assumed $\alpha$ as the annual growth rate for 1989-1990. It follows that

$$
Y_{1989}^{*}=\frac{Y_{1990}}{\left(1+\alpha_{90}\right)}
$$

For the remaining years (1980-1988), we had the annual growth rates $(\beta \mathrm{i})$ provided by the National Statistics Institute of Portugal. Being:

$\beta_{i}$ : effective growth in the year $i(i=1980, \ldots, 1989)$

\footnotetext{
${ }^{12}$ Manufacturing corresponds to section D "Secção D" and is formed by 14 subsections (industries), according to the Portuguese Classification of the Economic Activities "CAE - Rev. 2.1".

${ }^{13}$ Manufacturing employed about 1.153.914 employees in 1980 and 886.253 in 2003.

${ }^{14}$ Authors' own calculations based on values of "Inquérito Permanente ao Emprego" (1981) from the National Statistics Institute of Portugal.

${ }^{15}$ Annual compound growth rate $=\left[\exp \left(\frac{1}{t} \times\left(\ln Y_{i t}-\ln Y_{i 0}\right)\right)-1\right] \times 100$ Being:

$t=$ Number of Years

$Y_{i t}=$ Value in the final Year

$Y_{i 0}=$ Value in the base Year
} 


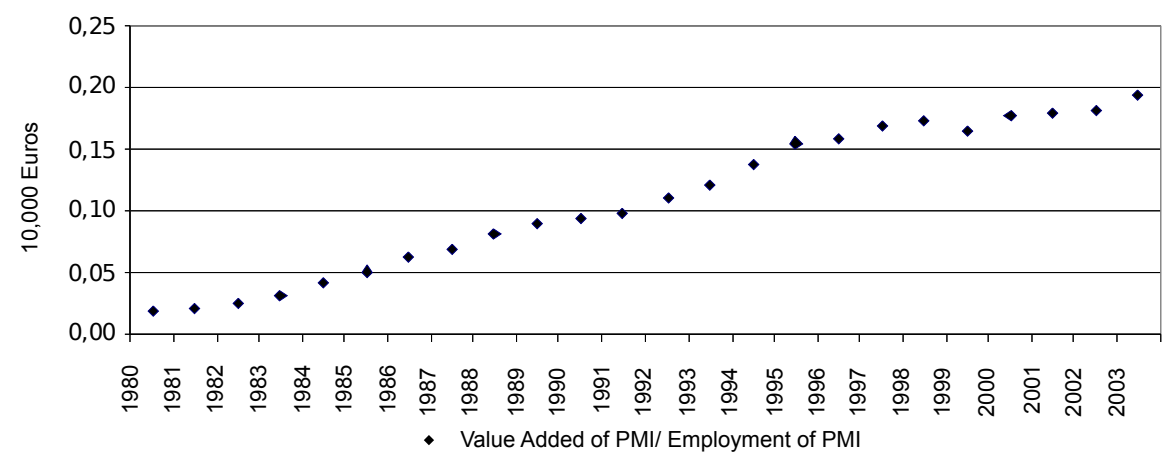

Source: Authors' own calculations based on values of "Estatísticas Industriais" (1980-1989) and "Estatísticas das Empresas" (1990-2003) from the National Statistics Institute of Portugal.

Note: Value added of PMI at constant prices (consumer price index - base year 1986).

Figure 2: Labour productivity of the Portuguese manufacturing industry (19802003)

$Y_{i}^{*}$ : calculated value for the year $i$

$$
Y_{i}^{*}=\frac{Y_{(i+1)}^{*}}{\left(1+\beta_{(i+1)}\right)} \text { being } i(\text { year })=1980, \ldots, 1988
$$

Starting with 1988,

$$
Y_{1988}^{*}=\frac{Y_{1989}^{*}}{\left(1+\beta_{89}\right)}, Y_{1987}^{*}=\frac{Y_{1988}^{*}}{\left(1+\beta_{88}\right)}, Y_{1986}^{*}=\frac{Y_{1987}^{*}}{\left(1+\beta_{87}\right)}, \ldots
$$

Having the values for 1988, we applied the effective annual growth rates and calculated the $\mathrm{Y}^{*} i$ for the remaining years by backward induction.

\section{Descriptive statistics}

Looking in detail at the labour productivity in the PMI over a long time period, we verify that productivity in manufacturing has increased considerably, as result of both, a decline in employment and an increase in value added.

The period under analysis can be divided in two cycles. The first cycle runs from 1980-1985, and the second from 1985-2003. The first period is characterized by moderate productivity growth. Aguiar \& Martins (2004) explain the developments based on the international crisis in the aftermath of the Oil Shocks of 1973 and 1979, internal policies and the austerity implied by the stability plans negotiated with the International Monetary Fund (IMF) ${ }^{16}$. From 1985 onwards, industrial productivity accelerated, albeit in a context of "deindustrialization"17. Aguiar \& Martins (2004) proposed four main reasons for this evolution, namely the macroeconomic results of the stabilization plans, institutional and political stability fostering private initiative, accession to the European Economic Community (EEC) in 1986, and favourable international conditions (depreciation of the USD, decline in interest rates and in the Oil Prices).

\footnotetext{
${ }^{16}$ Stabilization Plan of 1978-1979, and the Second Stablization Plan of 1983-1984.

${ }^{17} \mathrm{~A}$ decline in the weigh of the industry in the overall economy.
} 


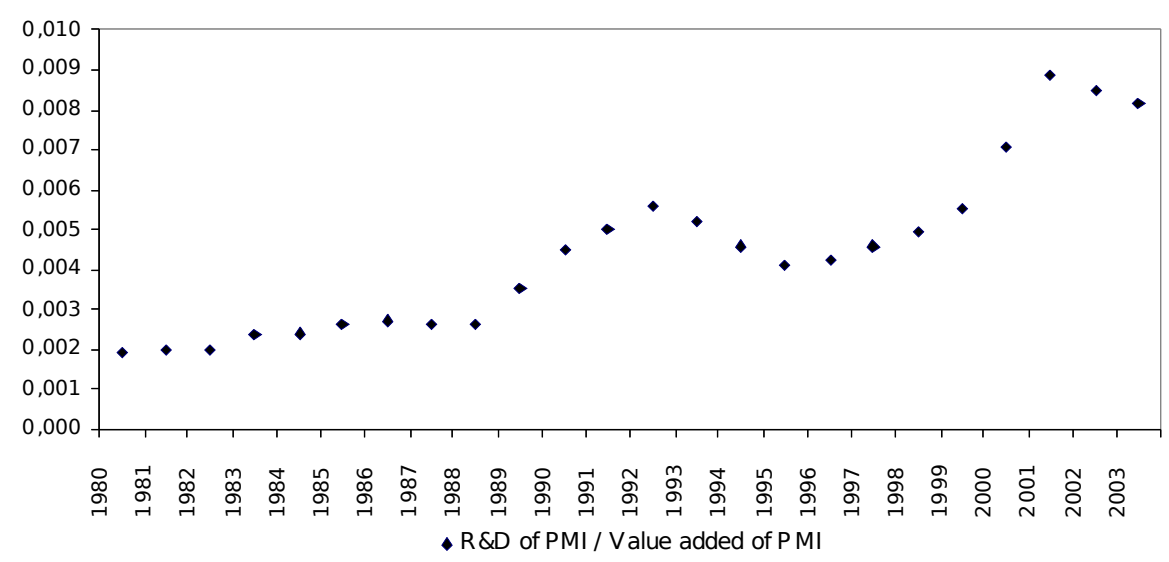

Source: Own elaboration based on "Estatísticas Industriais" (1980-1989), "Estatísticas das Empresas" (1990-2003), "Anuário Estatístico" (1986-1989) and "Anuário Estatístico de Portugal" (1990-2003) from the National Statistics Institute of Portugal, as well as data from the R\&D Survey by the "Observatório da Ciência e do Ensino Superior".

Figure 3: Private R\&D intensity in Portuguese manufacturing industry

Although labour productivity in the PMI and in the Portuguese economy in general has registered a positive evolution in recent decades, it continues to remain significantly below the European average. The above discussion highlights that Portugal has to generate faster productivity growth.

The data also suggest that with a view to competitiveness it is not enough to look at capital per worker, but that innovation and an adequate business environment (factors considered by TFP) are fundamental with a view to competitiveness and growth, an issue focused by the Lisbon Agenda. Looking at the data on innovative activities in Graph 3, the positive trend from 1988 onwards is clear, in spite of the slight decline in the early 1990s and 2000s mainly associated with the international crisis (Biscaya et al. 2002). Nevertheless, business R\&D is still relatively lower than in the EU. The small size of the firms has been advanced as one of the possible explanations for the low levels of R\&D in Portuguese industry.

Another set of reasons are related to the industrial structure, namely the strong concentration in low-tech sectors (Gonçalves et al. 2000). Indeed, the importance of medium and high-tech sectors on the innovation performance of country is clear when we look at the distribution of the investments in R\&D. For the case of the PMI, Table 4 shows a concentration in the high-technology and medium-high-technology industries. Machine equipment, electric and optical equipment as well as the transport equipment industries represented in 2003 about $45 \%$ of the total expenditure in R\&D carried out by the PMI. Coke and petroleum, chemicals and products must also be mentioned on account of their $25 \%$ expenditure.

Regarding industrial structure, Portugal is often characterised as specializing in labour intensive industries. An analysis of the employment structure within manufacturing reinforces this idea. In 2003, textiles still accounted for 26 percent of employment in Portuguese manufacturing. Food, beverages and tobacco followed by basic metals and metallic products account for 12 and 10 percent, respectively, of the manufacturing employment. Machine equip- 
Table 4: Structure of expenditure in R\&D (current prices), 2003

\begin{tabular}{|c|c|c|c|}
\hline & Branch of Economic Activity & $\begin{array}{c}\text { R\&D } \\
\text { (thousand } € \text { ) }\end{array}$ & $\begin{array}{c}\mathrm{R} \& \mathrm{D} \\
(\%)\end{array}$ \\
\hline $\mathrm{D}$ & Manufacturing & $150,957.9$ & 100 \\
\hline DA & Food, beverages and tobacco & $5,651.0$ & 4 \\
\hline $\mathrm{DB}$ & Textiles & $10,509.9$ & 7 \\
\hline DC & Fur and leather & 733.3 & - \\
\hline DD & Wood, cork and products & $3,718.0$ & 2 \\
\hline $\mathrm{DE}$ & $\begin{array}{l}\text { Pulp, paper, paper products, publishing } \\
\text { and printing }\end{array}$ & $2,987.7$ & 2 \\
\hline DF & Coke and petroleum & $37,249.0$ & 25 \\
\hline DG & Chemicals & $11,032.1$ & 7 \\
\hline $\mathrm{DH}$ & Rubber and plastics & $6,830.0$ & 5 \\
\hline DI & Non-metallic mineral products & $2,833.5$ & 2 \\
\hline DJ & Basic metals and metallic products & $15,874.7$ & 11 \\
\hline $\mathrm{DK}$ & Machinery equipment, n.e. c. & $44,518.3$ & 29 \\
\hline DL & Electric and optical equipment & $7,346.8$ & 5 \\
\hline DM & Transport equipment & $1,673.6$ & 1 \\
\hline
\end{tabular}

Source: Adapted from the R\&D Survey (2003) by the "Observatório da Ciência e do Ensino Superior".

Note: Due to statistical secrecy reasons, the results of subsections DF and DG are presented as a whole.

ment, electric and optical equipment and transport equipment altogether account for only 15 percent of manufacturing employment in 2003.

The analysis of the PMI in terms of value-added reveals once more the weight of textiles, food, beverages and tobacco, with 14 and 13 percent of the PMI value-added in 2003. Machinery equipment, electric and optical equipment and transport equipment, account altogether for 19 percent of the value added in 2003.

Regarding specialization in perspective with Europe, three groups of countries can be identified within the EU-15 $5^{18}$. The first one includes countries specialized in high labour skill sectors (Belgium, France, and Luxembourg) and high to intermediate labour skills (Denmark, Finland, Sweden and to a lesser extent the United Kingdom). The second group includes countries specialized in the two lowest categories of labour skills and includes Portugal (apart from Austria, Spain, Greece and Italy). Note that in the study by DG Enterprise of the European Commission (2006), Portugal is characterized as specializing ${ }^{19}$ in leather and footwear, clothing, textiles, wood and products of wood, financial intermediation, radio and television receivers. Finally, there is a group of countries without a clear specialization profile (Germany,

\footnotetext{
${ }^{18}$ The value was calculated for the 15 countries that were members of the European Union up to 2004 for which data was available.

${ }^{19}$ The indicator for sectoral specialization of EU-15 member states presented here compares a country's value-added shares across industries with the average EU-15 industry's shares. The indicator is defined, for country ' $i$ ' and industry ' $j$ ', with VA being value added and EU corresponding to the EU-15, so as to indicate specialization equal to the EU average if the value is 1 for a given industry. The higher the value of the indicator, the higher the country's specialization compared with the EU average. $S_{i, j}=\left(\begin{array}{c}V A_{i, j} / \sum V A_{i, j} \\ j\end{array}\right) /\left(\begin{array}{c}V A_{E U, j} / \sum V A_{E U, j} \\ j\end{array}\right)$
} 
Table 5: Structure of employment, 2003

\begin{tabular}{llrc}
\hline & \multicolumn{1}{c}{ Industry } & No. employees & $\begin{array}{c}\text { Employees } \\
\text { (\% on total) }\end{array}$ \\
\hline D & Manufacturing & 886,253 & 100 \\
DA & Food, beverages and tobacco & 106,277 & 12 \\
DB & Textiles & 222,602 & 26 \\
DC & Fur and leather & 62,333 & 7 \\
DD & Wood, cork and products & 48,611 & 5 \\
DE & Pulp, paper, paper products, & 53,428 & 6 \\
& publishing and printing & & \\
DF & Coke and petroleum & 2,136 & - \\
DG & Chemicals & 21,715 & 2 \\
DH & Rubber and plastics & 64,711 & 3 \\
DI & Non-metallic mineral products & 91,519 & 7 \\
DJ & Basic metals and metallic products & 43,124 & 10 \\
DK & Machinery equipment, n.e. c. & 49,027 & 5 \\
DL & Electric and optical equipment & 34,168 & 6 \\
DM & Transport equipment & 62,031 & 4 \\
DN & Other manufacturing industries & & 7 \\
\hline Source & Own & & \\
\hline
\end{tabular}

Source: Own elaboration based on "Estatísticas das Empresas" (2003), from the National Statistics Institute of Portugal.

the Netherlands and Ireland). This implies that the distribution of value added is very similar to the one of the EU-15 as a whole.

Following the OECD high-tech classification of manufacturing industries ${ }^{20}$, we may analyse the PMI's employment structure at this level. In this regard, great stability is verified over the years, where the low-technology and medium-low-technology industries are visibly dominant. These industries as a whole represent in 2006 about $84 \%$ of the total employment in the Portuguese manufacturing, while in the set of four countries considered in the Table 7 they don't represent more than $58 \%$.

As seen, the structure of the PMI clearly shows the weight of low and medium to low technology sectors (Godinho \& Mamede 2004). Nevertheless, the relationship between structure and productivity must not disregard the starting level. An increase in the weight of high and medium to high technology industries of about 1 percent may have a significant impact on economies with a very low starting point (Kaloudis \& Smith 2005). Otherwise, even if an industry's employment share remains constant over time, there may have been a lot of entry and exit of firms and innovation (products and processes) in that industry. As we mentioned before, high and medium to high technology industries are the most highly innovative within Portuguese manufacturing. These aspects need to be considered.

Hence, the emergence of competitors with a broad spectrum of comparative advantages in industrial activities has put the issue of the manufacturing industry's future in industrialized countries on the agenda. The discussion of whether Europe can hold on to manufacturing assumes particular relevance for economies such as the Portuguese one, strongly open and relatively specialized in labour-intensive sectors.

\footnotetext{
${ }^{20}$ In appendice 1 we provide the OECD High-tech classification of manufacturing industries.
} 
Table 6: Structure of value-added (current prices), 2003

\begin{tabular}{llrr}
\hline & \multicolumn{1}{c}{ Industry } & VA (thousand $€$ ) & VA (\%) \\
\hline D & Manufacturing & $18,470,272$ & 100 \\
DA & Food, beverages and tobacco & $2,604,169$ & 13 \\
DB & Textiles & $2,638,017$ & 14 \\
DC & Fur and leather & 668,708 & 4 \\
DD & Wood, cork and products & 806,520 & 4 \\
DE & Pulp, paper, paper products, & $1,803,996$ & 10 \\
& publishing and printing & & \\
DF & Coke and petroleum & 523,801 & 3 \\
DG & Chemicals & $1,049,753$ & 6 \\
DH & Rubber and plastics & 719,447 & 4 \\
DI & Non-metallic mineral products & $1,711,180$ & 9 \\
DJ & Basic metals and metallic products & $1,719,353$ & 9 \\
DK & Machinery equipment, n.e. c. & $1,026,060$ & 6 \\
DL & Electric and optical equipment & $1,346,985$ & 7 \\
DM & Transport equipment & $1,018,573$ & 6 \\
DN & Other manufacturing industries & 833,709 & 5 \\
\hline
\end{tabular}

Source: Own elaboration based on "Estatísticas das Empresas" (2003), from the National Statistics Institute of Portugal.

Table 7: Employment structure in terms of industries by technological intensity $(\%)$

\begin{tabular}{|c|c|c|c|c|c|c|c|}
\hline \multirow[t]{2}{*}{ Global Technological Intensity } & \multicolumn{4}{|c|}{ Portugal } & \multicolumn{3}{|c|}{$\begin{array}{l}\text { Germany+UK } \\
+ \text { Italy+France }\end{array}$} \\
\hline & 1985 & 1994 & 2003 & 2006 & 1985 & 1994 & 2006 \\
\hline High-tech industries & 3 & 3 & 3 & 2 & 9 & 9 & 7 \\
\hline Medium-high-tech industries & 12 & 13 & 13 & 14 & 32 & 33 & 35 \\
\hline Medium-low-tech industries & 26 & 25 & 21 & 84 & 25 & 24 & 58 \\
\hline Low-tech industries & 59 & 59 & 63 & & 34 & 34 & \\
\hline Total manufacturing & 100 & 100 & 100 & 100 & 100 & 100 & 100 \\
\hline
\end{tabular}

Source: Adapted from Godinho \& Mamede (2004) except 2003 (authors' own calculations based on values of "Estatísticas das Empresas" (2003) from the National Statistics Institute of Portugal) and 2006 (own calculations based on values of "Science, technology and innovation in Europe" (2008) from Eurostat).

* For comparison we report the average from Germany, United Kingdom, Italy and France 
The model and variables

Previously we highlighted the increase in PMI's productivity as well as the developments regarding innovation and structural change. Following the literature reviewed in section 2, three hypotheses are tested for Portuguese manufacturing over the period 1980-2003:

1. Public R\&D activity has a positive impact on manufacturing productivity;

2. Business R\&D in the high-technology and medium-high-technology industries has a positive impact on manufacturing productivity;

3. An increase in high-technology and medium-high-technology industries on manufacturing employment has a positive impact on the manufacturing productivity.

If an exact innovation model in all its multiple dimensions was available, we would be able to fully understand the complex nature of innovation (Mairesse 2004). However, such a model does not exist. Nevertheless, as Mairesse (2004) notes, "it is worth trying to account for innovation differences, even in a crude and simplified manner."

Once we have overcome the problem of the time-coherence of the series, we obtain 24 usable observations. With a small sample size such as ours, the empirical analysis should be kept to a minimum level of complication, since good small-sample properties of estimation methods are generally difficult to obtain.

Since productivity is, among other things, a result of innovation, and innovation is, among other things, a result of R\&D (Mairesse \& Mohnen 2002), we present a multiple regression model that allows us to quantify the relation between a dependent variable $(\mathrm{Y})$ and a set of independent variables $\left(X_{0}, X_{1}, X_{2}, \ldots, X_{n}\right)$ through the estimation of their parameters $\left(\beta_{0}, \beta_{1}, \beta_{2}, \ldots, \beta_{n}\right)$ :

$$
Y_{t}=\beta_{0}+\beta_{1} X_{t 1}+\beta_{2} X_{t 2}+\ldots+\beta_{n} X_{t n}+u_{t}, \quad \text { with } \quad X_{0}=1 ; t=1,2 \ldots, T
$$

or

$$
Y_{t}=\beta_{0}+\sum_{i=1}^{n} \beta_{i} X_{t i}+u_{t}, \quad \text { with } \quad X_{0}=1 ; i=1,2 \ldots, n ; t=1,2, \ldots T .
$$

Based on equation (1), we developed an econometric model in order to explain the PMI's labour productivity.

The econometric model includes public R\&D activity by the Portuguese State (H1) and business R\&D in medium and high-tech industries so as to analyze the relationship between R\&D and the PMI's labour productivity, giving particular emphasis to R\&D in medium and high intensive sectors (H2).

To test Hypotheses 3 we included as a variable the weight of medium to high-tech industries on total manufacturing employment, as this group of industries registered a slight increase over the period under analysis. In our study we considered the machine equipment (ME), electric and optical equipment (EOE) and transport equipment (TE) sectors, which are classified by OECD as medium to high-tech intensive sectors.

$$
Y_{t}=\beta_{0}+\beta_{1} X_{t 1}+\beta_{2} X_{t 2}+\beta_{3} X_{t 3}+u_{t}
$$

with $X_{0}=1 ; t=1,2, \ldots, 24$ where: 
$Y$ stands for PMI labour productivity, which is represented by the logarithm of the ratio between the value added of PMI (constant prices: base year 1986) and employment in the PMI;

$X_{1}$ stands for public R\&D intensity which is represented by the logarithm of the ratio between the Portuguese State's expenditure in $R \& D$ and the value added of PMI;

$X_{2}$ stands for the private intensity in R\&D of ME, EOE and TE, which is represented by the logarithm of the ratio between private expenditure in $R \& D$ by these three industries and the value added relative to $M E, E O E$ and TE;

$X_{3}$ stands for the proportion that $\mathrm{ME}, \mathrm{EOE}$ and TE as a whole have in the total employment of the PMI, which is represented by the logarithm of the ratio between employment in these three industries and total employment in the PMI.

We further introduced a number of lags for R\&D related variables (X1 and $\mathrm{X} 2$ ). The introduction of lags is based on the fact that R\&D expenditures may well take time to affect output. Indeed, investments in R\&D do not normally produce immediate results because time is necessary before new knowledge can be developed, so that it can be disseminated and commercialized in the economy (Griliches 1979).

Seeing that a significant number of studies have demonstrated that this lag varies on average between one and four years (Mansfield et al. 1971, Pakes \& Schankerman 1984, Acs \& Audretsh 1988), we also estimate our model considering a temporal lag of one, two, three and four years for the variables related to R\&D intensity (X1 and X2).

\section{Estimation results}

Tables 8 and 9 present the values obtained from the estimation of the model through the method of ordinary least squares (OLS). In the original model without any temporal lag for the independent variables (column i) we observed a positive autocorrelation ${ }^{21}(\rho>0)$ with the Durbin-Watson's value (d $=0.4728)$ falling in the interval $] 0 ; d L\left[{ }^{22}\right.$. In order to correct eventual autocorrelation problems, the results presented in the tables were estimated using Newey-West estimators (model a), and 1-year lag for the dependent variable (model b), respectively. As shown in Table 8 , the autocorrelation persisted in the model $\mathrm{a}^{23}$. The results of Table 9 demonstrate that the inclusion of a 1 -year lag for PMI labour productivity eliminates the positive autocorrelation in the residuals.

We also estimated the models considering a temporal lag of one, two, three and four years for the variables related to R\&D intensity $\left(X_{1}\right.$ and $\left.X_{2}\right)$.

Our results show that only Hypothesis 2 is partially supported, as the coefficient of the independent variable $X_{2}$ is the only one statistically significant

\footnotetext{
${ }^{21}$ In this situation, an increase in the labour productivity in the period $t$ generates a positive impact on the residue of the following period (period $t+1$ ).

${ }^{22}$ The value of $\mathrm{dL}$ with a $5 \%$ significance level is given by 1.101 .

${ }^{23}$ Given the small sample size, remedies like robust Newey-West standard errors and covariances should be used carefully, since their consistency properties under autocorrelation and heteroskedasticity are only crudely approximated in small samples (AND 2008).
} 
in both models. Therefore, only $X_{2}$, the variable measuring the private intensity in R\&D of ME, EOE and TE, contributes to the explanation of the PMI labour productivity growth. However, in model b the effect of $X_{2}$ becomes significant after the 3-year lag, suggesting that the effect of intensity in private intensity of $R \& D$ is not immediate.

Hypothesis 1 and 3 on the other hand are not confirmed, as the coefficients of variables $X_{1}$ and $X_{3}$ are not statistically significant. Nevertheless, the coefficients of variable $X 1$ are mainly positive, and in model $b$ the signal of $X_{3}$ becomes positive with a 4 -year lag.

When included in model $b$, the variable $Y_{-1}$ is always statistically significant at the $1 \%$ level, which means that the last values of productivity in the manufacturing industry exert a positive effect on the productivity values in the following years.

The independent variables as a whole reflect a good explanatory capacity for the PMI's labour productivity, when FObserved is higher than FCritical at the $1 \%$ significance level. The high R2 reflects a good adjustment of the models. A substantial part of the total variation in the PMI's labour productivity is explained by the independent variables considered in the models.

\section{Discussion and implications}

Our model makes many simplifying assumptions, but its main virtue is that it takes into consideration the indirect impact of public R\&D as well as of medium and high-tech industries' R\&D in other sectors where the R\&D effort is made. Our results confirm the importance of business $R \& D$ in the medium to high-tech sectors, as they stimulate productivity growth. We further reveal that the direct impact and the inherent spillovers from private expenditure in $R \& D$ occur in a relatively shorter period of time than that of public investment. $R \& D$ is overwhelming important, but, $R \& D$ expenditures may be only one part of the story behind the Portuguese backlog. Factors such as absorptive capacity, interactions within the S\&T system, regulation and stability may be just as important in achieving the TP ambition.

Regarding the role of structural change, the results deserve an in-depth analysis and the conclusions are not straightforward.

In the countries examined by Kaloudis \& Smith (2005), there was a clear tendency for the share of low-tech industries in manufacturing to decline during the period 1980-1999, while the share of high-tech industries increased. This applies to both production and employment. However, they concluded that among the OECD countries studied, structural change within manufacturing is not the direct cause of the growth process in advanced OECD economies. In our case we did not identify a decline (or growth) in the weight of technology intensive industries. Probably for that reason we could not confirm Hypothesis 3. Otherwise, the fact that high-tech sectors are growing faster than medium or low-tech sectors in manufacturing output, does not necessarily mean that high-tech contributes more to overall manufacturing growth or productivity growth. High-tech sectors are small, so even high growth rates can have a relatively diminutive overall impact.

Based on our findings for Hypothesis 3, we cannot hypothesize that productivity growth was primarily rooted in the creation of new sectors. The internal transformation of sectors that already existed and/or are growing has 


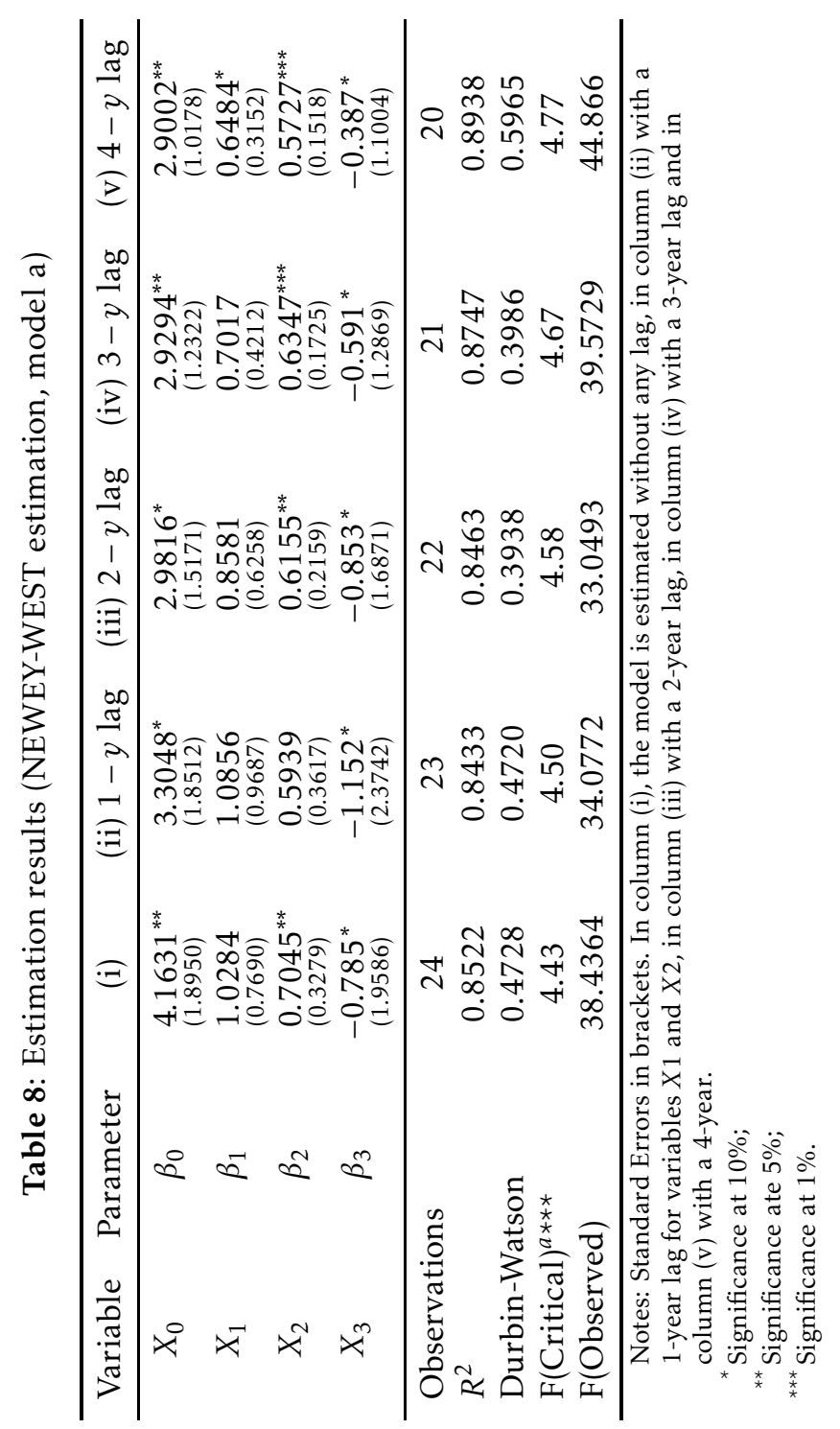




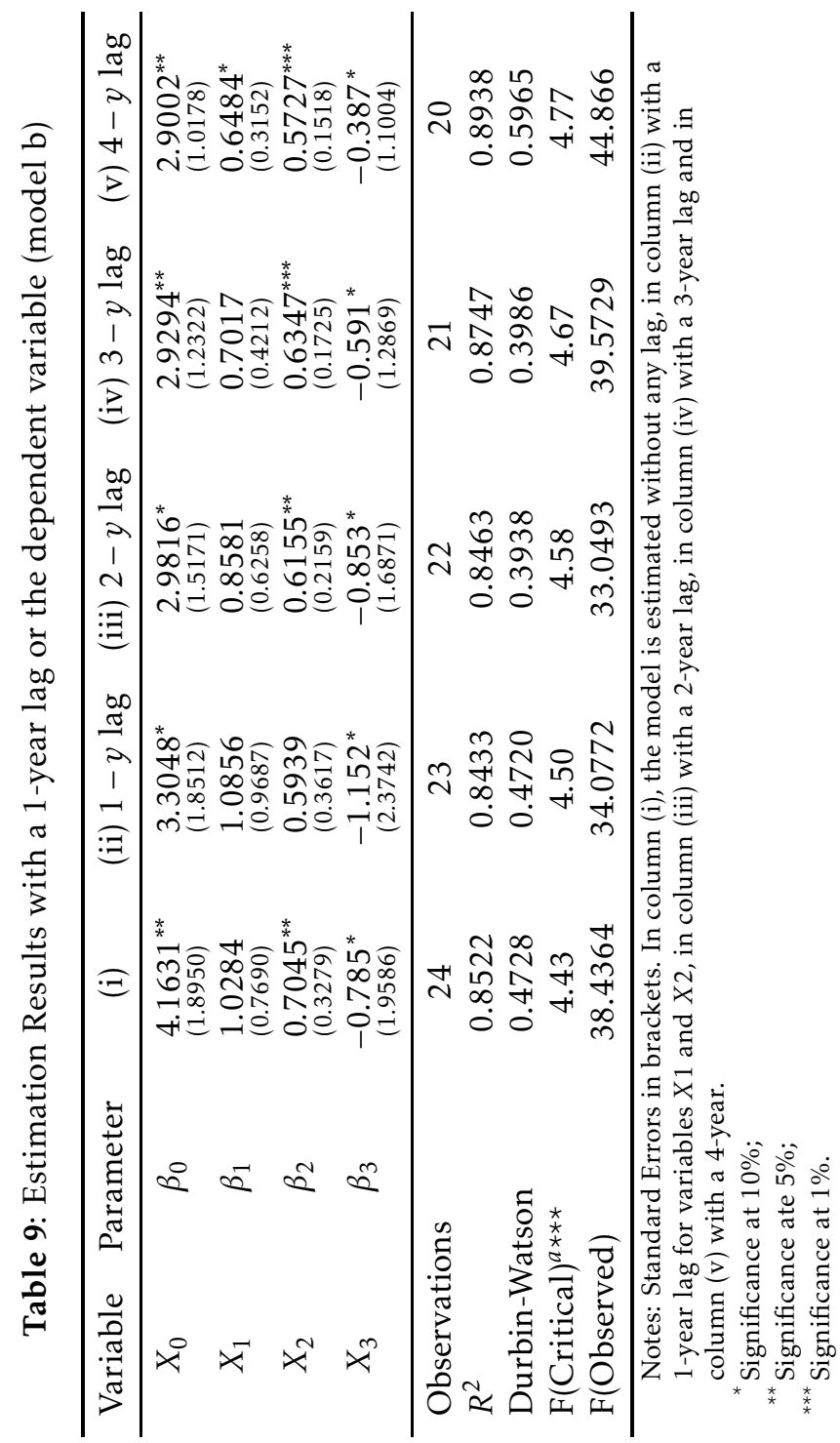


been overwhelming important. Hence, one must avoid those views that emphasize excessively the role of high-tech sectors in economic growth, which often underestimate processes of change and needs in those sectors of the economy with low R\&D investments. Finally, there has been structural change at the level of the economy as a whole, with a sustained rise in the share of services. This rise increase not support the high-tech argument, since services in general tend to be considered less R\&D intensive than high-tech manufacturing. Moreover, a developed service sector may well contribute significantly to manufacturing productivity, and this fact was not taken into account in our analysis.

But, as mentioned previously, even if an industry's employment share remains constant over time, there may have been a lot of entry and exit of firms and innovation (products and processes) in that industry. We verified that the innovation developments in the industries under consideration had a positive impact on productivity evolution in the time period analyzed. The dynamization of business R\&D in Portuguese manufacturing relies substantially on the dynamics of medium to high-tech industries, even if they do not gain considerable weight in the total employment or value-added.

Finally, from the analysis provided it is possible to derive future research avenues. As demonstrated by several studies, there has been a clear tendency for the share of low-tech industries in manufacturing to decline, while the share of high-tech industries has increased. It is nevertheless important to confront the claims of high-tech approaches with the evidence.

\section{Bibliography}

Acs, Z. \& Audretsh, D. B. (1988), 'Innovation in large and small firms: An empirical analysis.', American Economic Review 78, 678-690.

Adams, J. (1990), '.fundamental stocks of knowledge and productivity growth', Journal of Political Economy 98, 673-702.

Aguiar, A. \& Martins, M. (2004), O crescimento da produtividade da indústria portuguesa no século xx, Technical report, Faculdade de Economia da Universidade do Porto.

Ahn, S. (1999), Technology upgrading with learning costs: A solution for two productivity puzzles., Technical report, Paris OECD.

Aiginger, K. (2001), The impact of innovation: Evidence on the macro and sector level, Technical report, Austrian Institute of Economic Research.

AND, J. M. (2008), Median-unbiased estimation of higher order autoregressive/unit root processes and autocorrelation consistent covariance estimation in a money demand model., in 'XIV ANNUAL CONFERENCE ON COMPUTING IN ECONOMICS AND FINANCE,'.

Bessen, J. (2002), 'Technology adoption costs and productivity growth: The transition to information technology.', Review of Economic Dynamics 5, 443469.

Biscaya, P., Branco, R., Nunes, M. A., Simões, E. \& Nevado, V. C. (2002), Investimento, produtividade, competitividade e emprego: Evolução sectorial., Technical report, Lisboa: Observatório do Emprego e Formação Profissional. 
Brooks, H. (1994), 'The relationship between science and technology.', Research Policy 23, 477-486.

Bruland, K. \& Mowery, D. (2004), Innovation through time, Oxford University Press.

Carree, M. A. (2002), 'Technological progress, structural change and productivity growth: a comment.', Structual Change and Economic Dynamics 14, 109115.

Christensen, C. M. (1997), The Innovator's Dilemma: When New Technologies Cause Great Firms to Fail., Harvard Business School Press.

Crépon, B., Duguet, E. \& Mairesse, J. (1998), 'Research, innovation and productivity: An econometric analysis at the firm level.', Economics of Innovation and Technology 7, 115-158.

EUROPEANCOMISSION (2006), The european innovation scoreboard comparative analysis of innovation performance., Technical report, European Commission.

EUROSTAT (2004), Eurostat yearbook 2004: The statistical guide to europe., Technical report, Luxembourg: Office for Official Publications of the European Communities.

Fagerberg, J. (2000), 'Technological progress, structural change and productivity growth: a comparative study.', Structural Change and Economic Dynamics 11, 393-411.

Fraumeni, B. \& Okubo, S. (2005), R\&D in the national income and product accounts: A first look at its effect on GNP, in C. Corrado, J. Haltiwanger \& D. Sichel, eds, 'Measuring Capital in the New Economy', The University of Chicago Press.

Godinho, M. \& Mamede, R. (2004), Factores de convergência da economia portuguesa, in 'Portugal e a Sociedade do Conhecimento', Celta Editora.

Gonçalves, F. B., Godinho, M. M. \& Caraça, J. (2000), Políticas de c\&t e inovação em portugal: Trajectória, passado recente e perspectivas, in ' $\mathrm{CON}$ VERGE PROJECT MEETING'.

Griliches, Z. (1979), 'Issues in assessing the contribution of research and development to productivity growth', Journal of Economics 10, 92-116.

Griliches, Z. (1992), 'The search for R\&D spillovers', The Scandinavian Journal of Economics 94, 29-47.

Griliches, Z. (1995), R\&D and productivity: Econometric results and measurement, in 'Handbook of the Economics of Innovation and Technological Change.', Basil Blackwell.

Guellec, D. \& Van-Pottelsberge, B. (2001), 'R\&D and productivity growth: Panel data analysis of 16 oecd countries', OECD Economic Studies 2001, 103126. 
Jovanovic, B. \& Nuarko, Y. (1996), 'Learning by doing and the choice of technology.', Econometrica 64, 1299-1310.

Kaloudis, A. \& Smith, K. (2005), Structural change, growth and innovation: the roles of medium and low tech industries, 1980-2002., in 'CONFERENCE LOW-TECH AS MISNOMER: THE ROLE OF NON-RESEARCH-INTENSIVE INDUSTRIES IN THE KNOWLEDGE ECONOMY'.

Kiliçaslan, Y. \& Taymaz, E. (2004), Structural change, productivity and competitiveness in mena countries., Technical report, Ankara: Middle East Technical University.

Mairesse, J. (2004), Corporate innovation, research and productivity., Technical report, Institut National de la Statistique et des Éstudes Économiques.

Mairesse, J. \& Mohnen, P. (2002), Accounting for innovation and productivity: a comparison across four european countries., in 'DRUID SUMMER CONFERENCE 2002 ON INDUSTRIAL DYNAMICS OF THE NEW AND OLD ECONOMY - WHO IS EMBRACING WHOM?'.

Mansfield, E., Rapoport, J., Schnee, J., Wagner, S. \& Hamburger, M. (1971), Research and Innovation in the Modern Corporation., MacMillan.

Mowery, D. \& Rosenberg, N. (1989), Technology and the pursuit of economic growth, Cambridge University Press.

OECD (1994), The measurement of scientific and technological activities : proposed standard practice for surveys on research and experimental development: Frascati manual 1994, [5th ed.] edn, Organization for Economic Co-operation and Development.

Pakes, A. \& Schankerman, M. (1984), The rate of obsolescence of patents, research gestation lags, and the private returns to research resources., in ' $R \& D$, Patents, and Productivity', University of Chicago Press.

Poole, E. \& Bernard, J. T. (1992), 'Defence innovation stock and total factor productivity.', Canadian Journal of Economics 25, 438-452.

Rocha, F. (2005), Mudança estrutural na indústria brasileira: 19702001, in 'Indústria, Trabalho e Tecnologia: Subsídios à Política Pública.', EITT/PUCSP.

Romer, P. (1990), 'Endogenous technological change.', Journal of Political Economy 98, 71-102.

Salter, W. (1960), Productivity and Technical Change., Cambridge University Press.

Singh, L. (2004), 'Technological progress, structural change and productivity growth in manufacturing sector of south korea.', World Review of Science, Technology and Sustainable Development 1, 37-49.

Solow, R. (1957), 'Technical change and the aggregate production function', Review of Economic and Statistics 39, 312-320. 
Sveikauskas, L. (2007), R\&D and productivity growth: A review of the literature, Technical report, U.S. Bureau Of Labor Statistics.

Syrquin, M. (1988), Patterns of structural change., in 'Handbook of Development Economics', Elsevier.

Timmer, M. P. \& Szirmai, A. (2000), 'Productivity growth in asian manufacturing: the structural bonus hypothesis examined.', Structual Change and Economic Dynamics 11, 371-392.

Utterback, J. (1994), Mastering the Dynamics of Innovation, Harvard Business School Press.

Wieser, R. (2001), The impact of research and development on output and productivity: Firm level evidence., in 'Innovation and productivity of European manufacturing'.

Young, A. (1991), 'Learning by doing and the dynamic effects of international trade', Quartely Journal of Economics 106, 369-405. 


\section{Appendix A High-tech classification of manufacturing industries}

\begin{tabular}{|c|c|c|}
\hline $\begin{array}{c}\text { Global } \\
\text { Technological } \\
\text { Intensity }\end{array}$ & Economic Activity & $\begin{array}{l}\text { Average R\&D } \\
\text { Intensity (\%) }\end{array}$ \\
\hline High-technology & $\begin{array}{l}\text { Aeronautics and aerospacial } \\
\text { Pharmaceutic products } \\
\text { Office equipment and computing } \\
\text { Radio, TV and communication equipment } \\
\text { Medical instruments and optical } \\
\end{array}$ & $7.7-13.3$ \\
\hline $\begin{array}{l}\text { Medium-high } \\
\text { technology }\end{array}$ & $\begin{array}{l}\text { Machinery and electric equipment } \\
\text { Motorvehicles } \\
\text { Chemicals, except pharmaceutical industry } \\
\text { Rail and transport equipment n.e. } \\
\text { Other machinery and equipment }\end{array}$ & $2.1-3.9$ \\
\hline $\begin{array}{l}\text { Medium-low } \\
\text { technology }\end{array}$ & $\begin{array}{l}\text { Construction and naval repair } \\
\text { Coke, Petrol and nucler } \\
\text { Non-metallic mineral products } \\
\text { Basic metals and metallic products } \\
\text { Metallic products (except machinery and } \\
\quad \text { equipment) }\end{array}$ & $0.6-1$ \\
\hline Low-technology & $\begin{array}{l}\text { Recycling } \\
\text { Pulp, paper, paper products, publishing and } \\
\text { printing } \\
\text { Food, beverages and tobacco } \\
\text { Textiles } \\
\text { Fur and leather } \\
\text { Wood and cork products }\end{array}$ & $0.3-0.5$ \\
\hline
\end{tabular}

Source: OECD based on NACE rev. 1.1. 